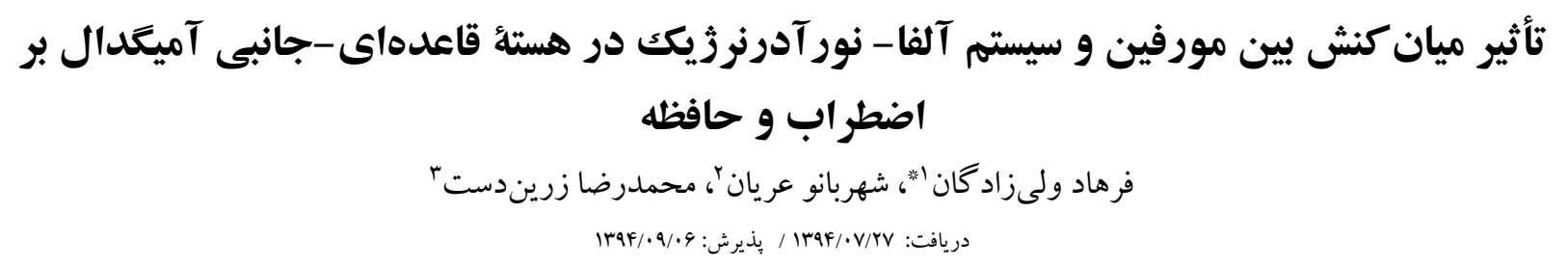

$$
\begin{aligned}
& \text { ' كروه زيستشناسى، دانشكدة علوم باية دانشكاه مازندران، بابلسر }
\end{aligned}
$$

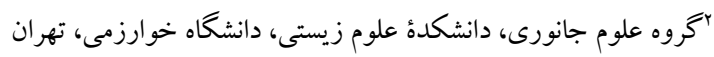

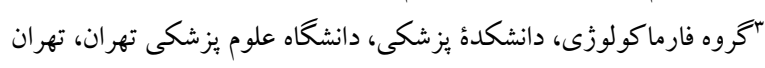

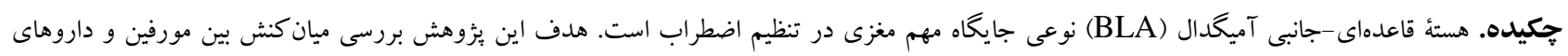

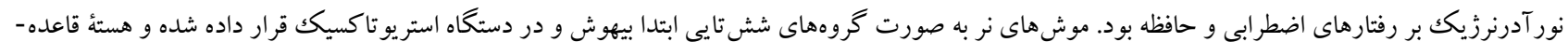

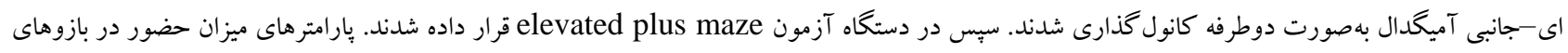

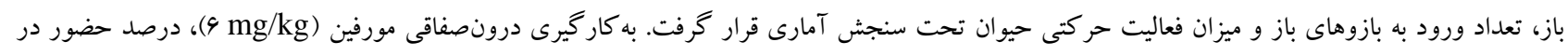

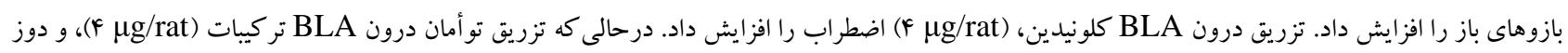

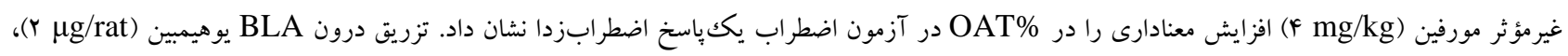

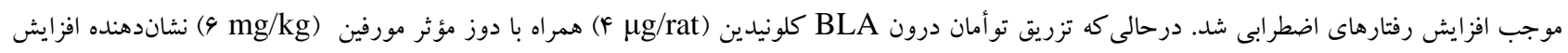

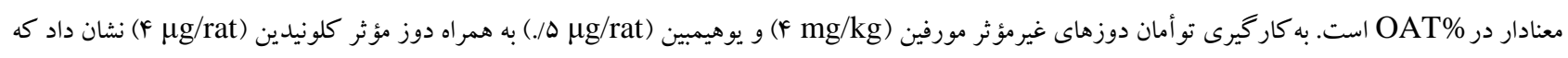

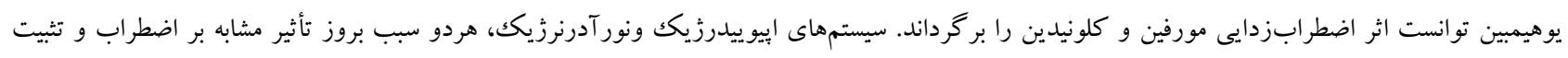

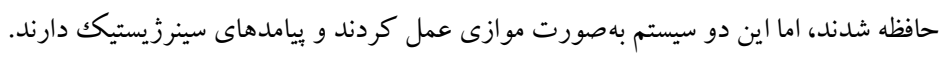
وازههاى كليدى. داروهاى نور آدرنرزيك،، ناحيه آميكدال، ماز صليبى شكل بالاتر از زمينه، إيوييدرزيك، موش صحرايى

\title{
Impact of the interaction between morphine and $\alpha$-noradrenergic system of basolateral Amygdala on anxiety-related behavior and memory
}

Farhad Valizadegan $^{1 *}$, Shahrbanoo Oryan ${ }^{2}$ and Mohammad Reza Zarrindast ${ }^{3}$

Received: 18/10/2015 / Accepted: 26/11/2015

${ }^{1}$ Department of Biology, Faculty of Sciences, Mazandaran University, Babolsar, Iran

${ }^{2}$ Department of Animal Biology, Faculty of Biological Sciences, Kharazmi University, Tehran, Iran ${ }^{3}$ Deprtment of Pharmacology, Faculty of Medicine, Medical Sciences University of Tehran, Tehran, Iran

*Correspondent author: fh_valizadegan@yahoo.com

\begin{abstract}
Basolateral Amygdala is an important site of anxiety. Interactions between $\alpha$-noradrenergic and opioidergic systems in Basolateral amygdale were, then, selected to investigate anxiety and memory. The elevated plus-maze was employed and the male wistar rats were tested. The site of BLA was cannulated bilaterally. Morphine $(4,5,6 \mathrm{mg} / \mathrm{kg})$ was injected to rats intraperitonealy, while clonidine $(1,2,4 \mu \mathrm{g} / \mathrm{rat})$ and yohimbin $(0.5,1,2 \mu \mathrm{g} / \mathrm{rat})$ were injected to BLA. Open arm time percentage (\%OAT), open arm entry (\%0AE) and locomotor activity were determined by this behavioral test. Retention was tested 24 hours later. Administration of morphine $(6 \mathrm{mg} / \mathrm{kg})$ increased the OAT\% in anxiety test, indicating anxiolytic-like effect. Intra Basolateral amygdala infusion of clonidine $(4 \mu \mathrm{g} / \mathrm{rat})$ has an anxiolytic-like effect. While co-administration of clonidine $(4 \mu \mathrm{g} / \mathrm{rat})$ and ineffective dose of morphine $(4 \mathrm{mg} / \mathrm{kg})$ showed significant increase of OAT\% in anxiety test; presenting anxiolytic response. Intra Basolateral amygdala administration of yohimbine $(2 \mu \mathrm{g} / \mathrm{rat})$ decreased OAT\% indicating of decrease anxiety-like behavior. While coadministration of intra Basolateral amygdala clonidine $(4 \mu \mathrm{g} / \mathrm{rat})$ and effective dose of morphine $(6 \mathrm{mg} / \mathrm{kg})$ showed a significant increase of OAT\%, presenting anxiolytic response; co-administration of ineffective doses of morphine (4 $\mathrm{mg} / \mathrm{kg})$ and yohimbine $(1 \mu \mathrm{g} / \mathrm{rat})$ with the effective dose of clonidine $(4 \mu \mathrm{g} / \mathrm{rat})$ showed that yohimbine could reverse the anxiolytic-like effect of morphine and clonidine. It should be noted that there are no significant changes in locomotor activity. The results indicate that morphine creates the compromise changes in adrenergic neurons of Basolateral amygdala by changing the $\alpha$-noradrenergic system on anxiety.
\end{abstract}

Keywords. noradrenergic drugs, amygdale region, elevated plus maze, opiopidergic, rat 
نشان مىدهد كه بسيارى از نورومودوليتورها ازطريق ميان كنش

با سيستم نورآدرنرزيك بر ذخيره حافظه تأثير مى گذارند

(Cahill et al., 1996)

آنتاكونيستهاى $\beta-$ آدرنرزيك تزريقشده به درون آميكدال تأثير تعديلى هورمونهاى استرس محيطى نظير ابىنفرين و كلوكو كورتيكوييدها بر حافظه را در يادگيرى اجتناب مهارى بلو كه مى كنند. تزريق آنتاكونيستهاى ه- آدرنرزيكك بهدرون آميگدال تأثير تعديل كننده حافظه القاء شده با داروهاى مؤثر بر بر براي

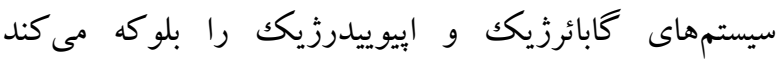
(Quirarte et al., 1997) درونبطنى آكونيست رسيتور

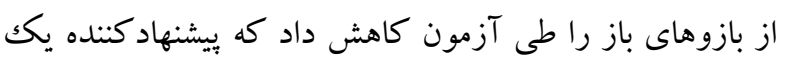

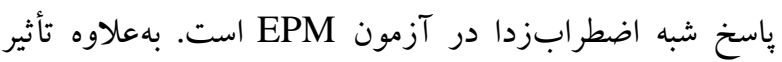
اضطرابزدايى مورفين در آزمون Retest ظهور مى كند. تأثير فوق بيشنهاد مى كند كه تثبيت حافظه ناخوشايند در اين كروروهـا

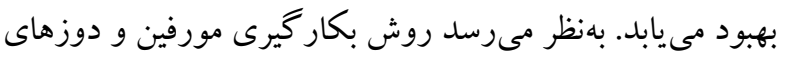

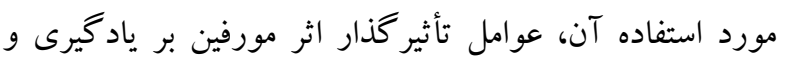

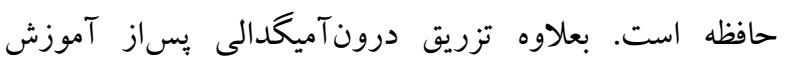

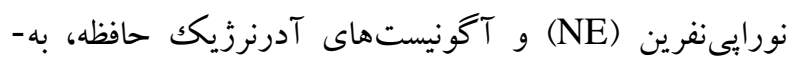
خاطرآورى اجتناب مهارى و آموزش آزمون آبى فضايى (spatial water-maze training) دهند و بهبود مىبخشند. اين نتايج ييشنهاد مى كنند كه آزادشدن نور آدرنالين بهدرون آميخدال القاشده با آموزش و داروها در

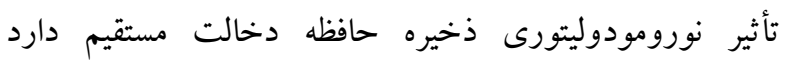
-Introini-Collison et al., 1995)، جانبى به دليل نقش آن در حافظه و يادگيرى براى مطالعه در اين تحقيق انتخاب شده است. از آنجاكه هيج مطالعهاى تعديل

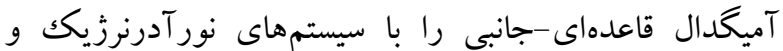
إييوئدرزيكك بر اضطراب و حافظه بررسى نكردهاست، هدف اين مطالعه ابتدا بررسى تأثير تزريقات آكونيست و آنتاكونيست Q- رسيتورهاى نور آدرنالين بهدرون آميخدال قاعدهاى-جانبى و بررسى نقش احتمالى آنها در رفتار مرتبط با اضطراب و شكل كيرى حافظه با استفاده از آزمون (EPM) و ثانياً بررسى تأثير

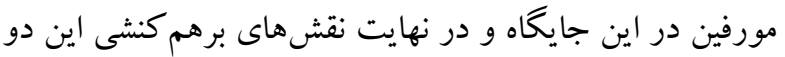

$$
\text { سيستم بر رفتارهاى ذكر شده است. }
$$

بهنظر مىرسد سازو كارهاى نوروشيميايى مختلفى مىتواند

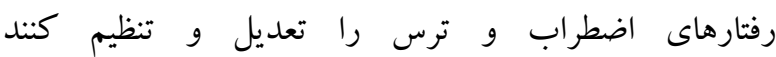

.(McGaugh, 2004)

اضطراب كه خود تحت كنترل آميكدال و هيبو كامب است تحت تأثير داروهاى اضطرابزدا قرار مى گيرد. درحالى كه ترس مقاومتر از اضطراب است و ممكن است ماده خاكسترى دورقنات سيلويوس (PAG) جايگاه اصلى ايجاد آن باشد. آميكدال يكى از مهمترين ساختارهاى مغز براى تثبيت و ذخيره حافظه عاطفى است و طى آزمايشهاى بسيار زيادى با استفاده از روشهاى آزمايشكاهى تحت بررسى قرار گرفته است و قادر است ازطريق پِاسخهاى ترس شرطى شده اندازهيرى شود Fanselow \& Poulos, 2005) برانگيختگى مرتبط با يادگيرى را در ديخر نواحى مغزى نظير كورتكس و هييو كامب تغيير مىدهد (McGaugh, 2004). از بى مهر كان تا انسان (McGaugh, 2004)، حافظه بلندمدت براى يكك واقعه مىتواند دقايق يا ساعاتى يساز يادگيرى

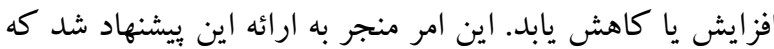
اشكال حافظه در طى زمان به آرامى شكل مى گيرند كه بديده تثبيت ناميده مىشود. اولين نشانه بروز اين يديده زمانى كشف شد كه Muller و Pilzecker در سال ..919 گزارش كردند كه حافظه اطلاعات تازه آموخته شده ازطريق يادگيرى ديخر بديده ها، كمى بِ إز اولين يادگيرى قطع مى شود. بس بساز آن، تثبيت

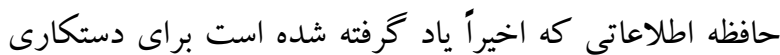

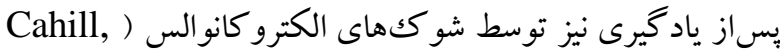

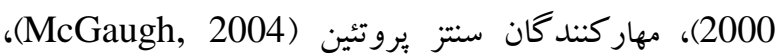
تزريقات دارويى (Duque et al., 2000) و تحريكك الكتريكى نواحى مختلف مغز (McGaugh, 1996) صورت

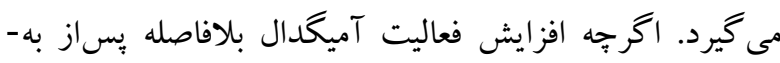

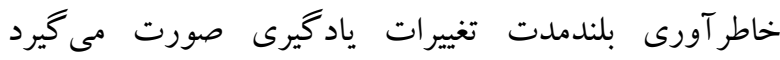
(Parent et al., 1995)، آميخدال جايگاه ذخيره اين حافظه نيست. آميكدال بردازشهاى مربوط به ذخيره حافظه را در نواحى مغزى به راه مىاندازد. نواحى ديخر در حافظه با تداعى نرئ معانى دخالت دارند (Liang et al., 1982). شواهد متعددى 
ثانيه به درون (BLA) فرستاده شد كه اين كار با استفاده از

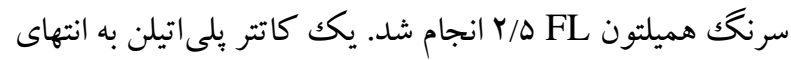
سوزن دندانيزشكى متصل شد و براى تزريق به كار رفت. يكك حباب هوا درون لوله بلى اتيلن بهعنوان يكك نشانگر براى مشاهده تزريق دقيق دارو ايجاد شد. سوزنها پِ از تكميل تزريق طى بـ بـ

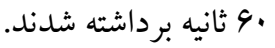

دستغاه آزمايش ماز صليبىشكل بالاتر از زمينه (EPM) ماز صليبىشكل بالاتر از زمينه (EPM)، يكك وسيله جوبى بهعلاوهاىشكل است كه از جهار بازو به شكل بهعلاوه ساخته

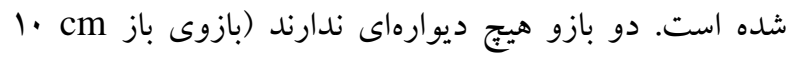

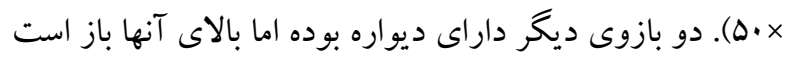

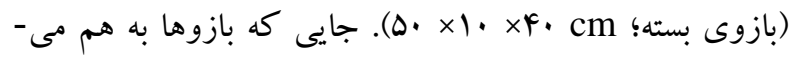
رسند يكك سكوى ميدانىشكل دارد با ابعاد • ا× •ا سانتىمتر.

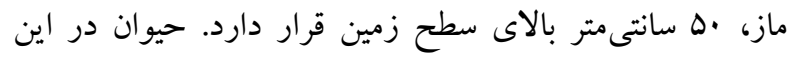
ميدان ميانى قرار مى گيرد. موشها بهصورت تكى در مركز باز

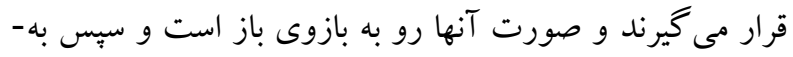
مدت ها دقيقه بهصورت آزاد در ماز گردش مر مئ كنند. تعداد ورود به بازوهاى باز، تعداد ورود به بازوهاى بسته و كل زمان كذرانده شده در بازوى باز و كل زمان كذراندهشده در بازوى

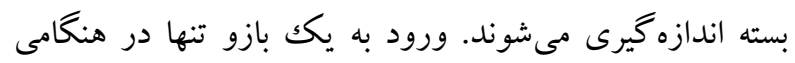

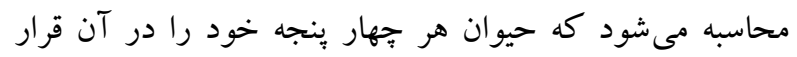

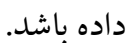

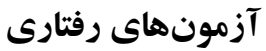

همان گونه كه قبلاً ذكر شد، ما از EPM براى سنجش ميزان حافظه و رفتارهاى شبهاضطرابى استفاده كرديم كه بر اساس يكك

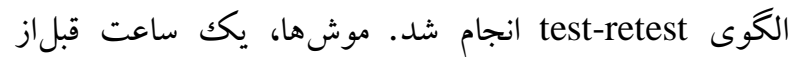
آزمون به اتاق آزمايش آورده مىشدند تا با محيط آزمايش

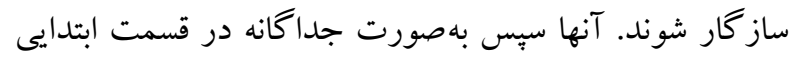

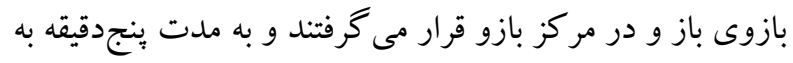

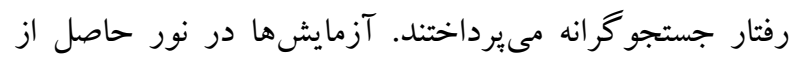

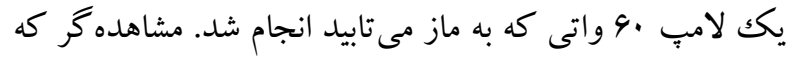

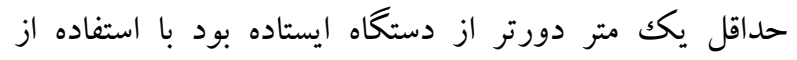

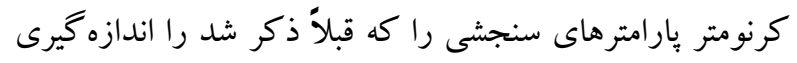

مواد و روشها

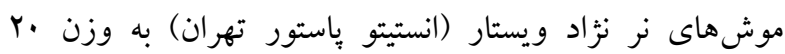
 حيوانات بهصورت جهارتيى در قفس هاى استاندارد قرار داشتند

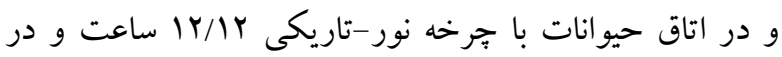

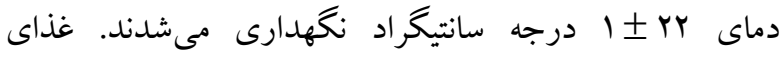

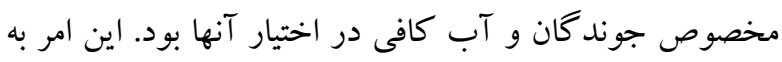

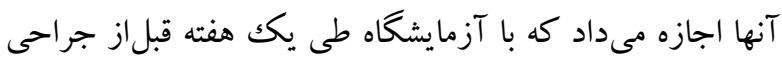

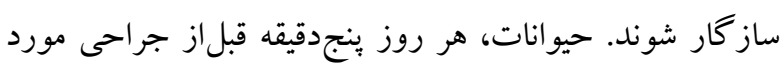

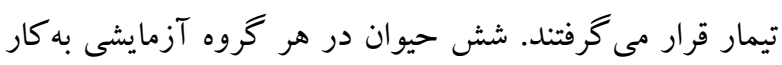

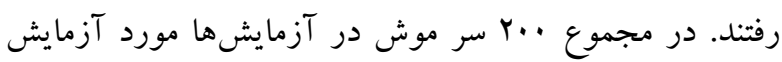

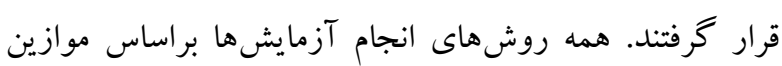

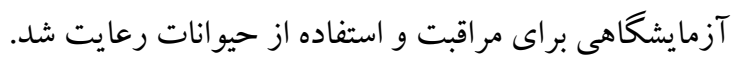

\section{جراحى استريوتاكسيك و تزريق دارو}

كتامين هيدروكلرايد · ل درصد بهعلاوه زايلزين r درصد بهورت درونبطنى به (Alpason, Woerdem, Holand) موشها تزريق شد و سبس آنها در دستخاه استريوتاكسى قرار

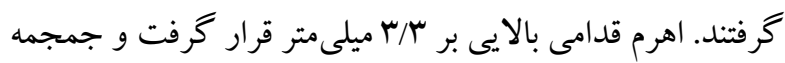

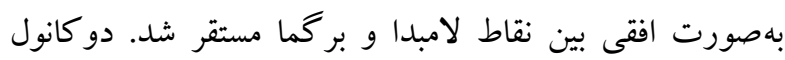

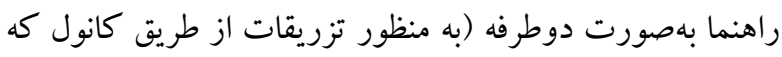

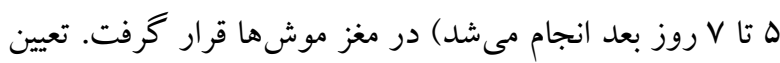

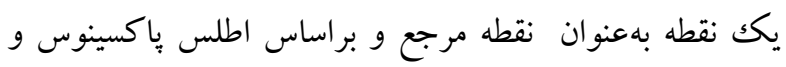

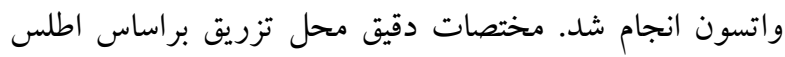
بهورت DV بود. كانولها در جمجمه بهوسيله رزين آكريليك محكم شدند. يكك سيم نازكى درون هر كانول راهنما، به منظور

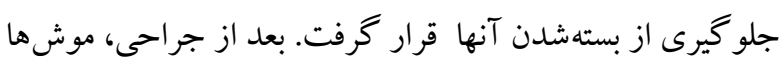

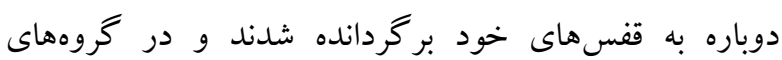

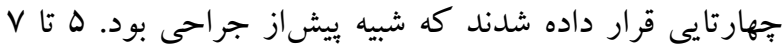
روز بعد موشها يكك تزريق درون (BLA) دوطرفه دريافت كردند كه بهوسيله سوزنهاى دندانيزشكى (YV - gauge) انجام شد كه بهدرون كانولهاى راهنما فرستاده شده بود. انتهاى سوزنهاى مذكور، ا ميلىمتر بالاى انتهاى كانولهاى راهنما

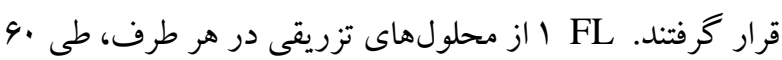


آزمايش قرار داده شد. تزريقات و انجام مراحل آزمون، همخى در ساعت · اصبح انجام شد. آزمايش مجدد (retest) نيز دقيقاً

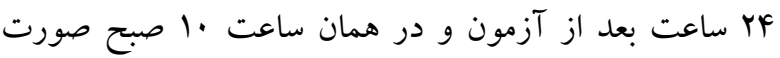

\section{تحليلهاى آمارى}

با بهدست آوردن نرماليته توزيع و همخنى واريانس، نتايج به صورت آمارى بهوسيله تحليل واريانس one- way ANOVA بررسى شدند. Mean I SEM براى مقايسه خروجىهاى ميان

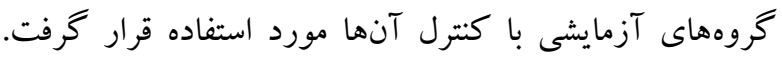
زمانى كه F-value، معنى دار بود، تحليل tukey) post-hoc

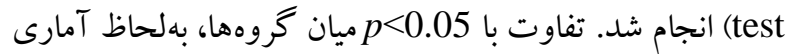

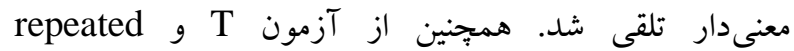
measures

تأثير مورفين بر رفتارهاى شباضطرابى و شكل حافظه

نتايج تحقيق حاضر نشان داد كه در تزريق درونصفاقى دوزهاى مختلف، مورفين، حداكثر تأثير رادر دوز ( (9 mg/kg) دركاهش تهريق اضطراب در مرحله test (بر زمان حضور در بازوى باز) ايجادكرد، اما تأثير معنادارى، بر تعداد ورود به بازوى باز و فعاليت حر كتى حيوان نداشت. آزمون One-way ساعت بعد انجام شد. آزمون Retest نشان داد كه مورفين بهصورت وابسته به دوز،

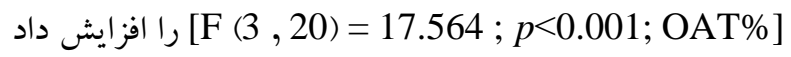
كه نشاندهنده يكك باسخ اضطرابزدا بود و حافظه بهوسيله مورفين بهبود ييدا كرده است. هيج تغيير معنىدارى در [F $(3,20)=2.2990 ; p<0.001$ OAE\%] فعاليت حركتى [F (3.20)= $1.017 ; p<0.001$ تغيير معنىدارى را نشان نداد (شكل (1).
مى كرد. ماز پس از هر آزمون توسط آب مقطر و الكل شسته و تميز مى شد. دادهاى خام ثبتشده براى محاسبه (OAT\%) (درصد زمان كذراندهشه در بازوى باز) به كار مىرفت. كل زمان گذراندهشده در بازوى بسته (OAE\%) مورد محاسبه قرار مى گرفت كه معيارى براى سنجش فقدان حافظه در طى آزمون

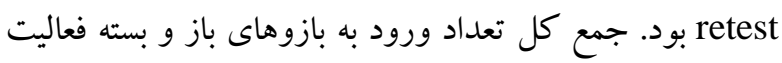

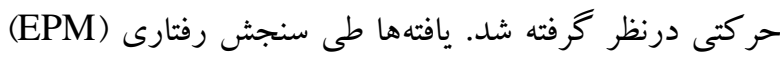

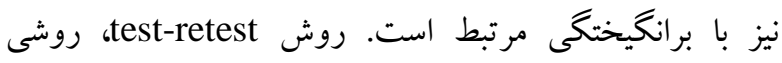
مناسب براى آزمايش وجوه مرتبط با اضطراب و حرافظه است.

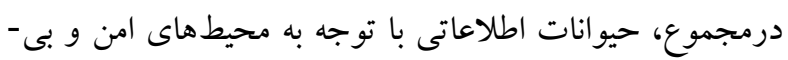

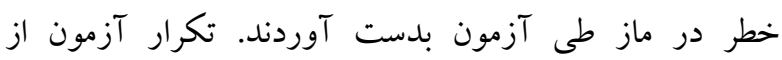

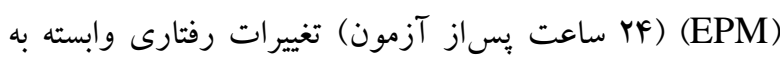

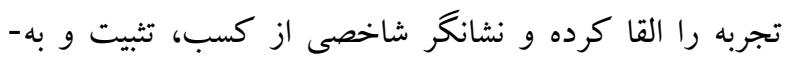
خاطر آورى است. هنكامى كه حيوان در يكك مرحله retest قرار مى گيرد، زمان جستجوى بازوى باز كاهش مى ايابد و اين هندي

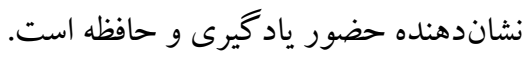
داروهاى مورد استفاده، زمان و نحوه تزريقات در اين مطالعه مخلوط داروهاى كتامين و زايلزين به نسبت هـ به براى بيهوشى حيوانات بهوسيله سرنگك انسولين در مقادير ميلى -

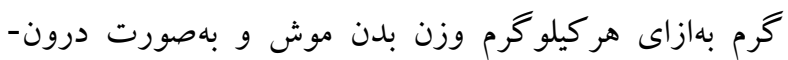

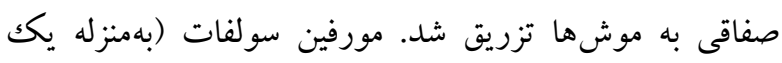

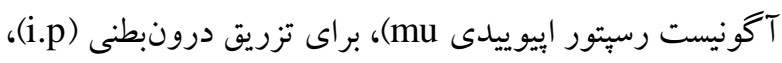

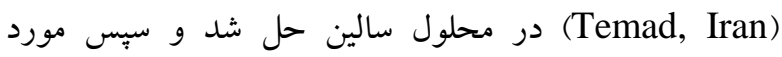

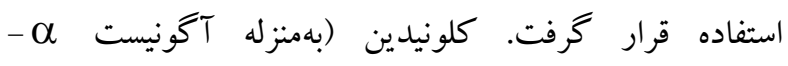

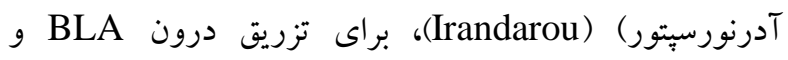

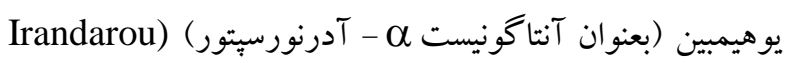
(Iran يوهيمبين در سالين استريل 9/• درصد حل شدند. سبس در مقادير بيش گفته بهوسيله سرنغك هميلتون و با استفاده از لوله

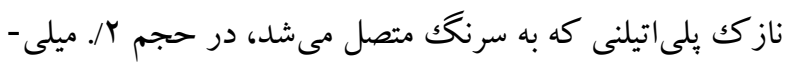

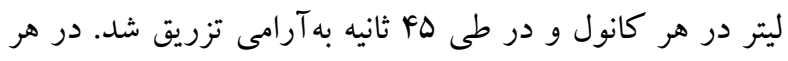
تزريق ابتدا مورفين و بعد از بـ دقيقه داروى مورد نظر تزريق شد فـ

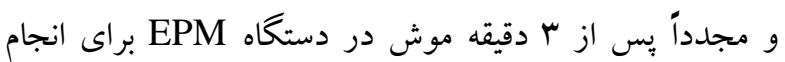



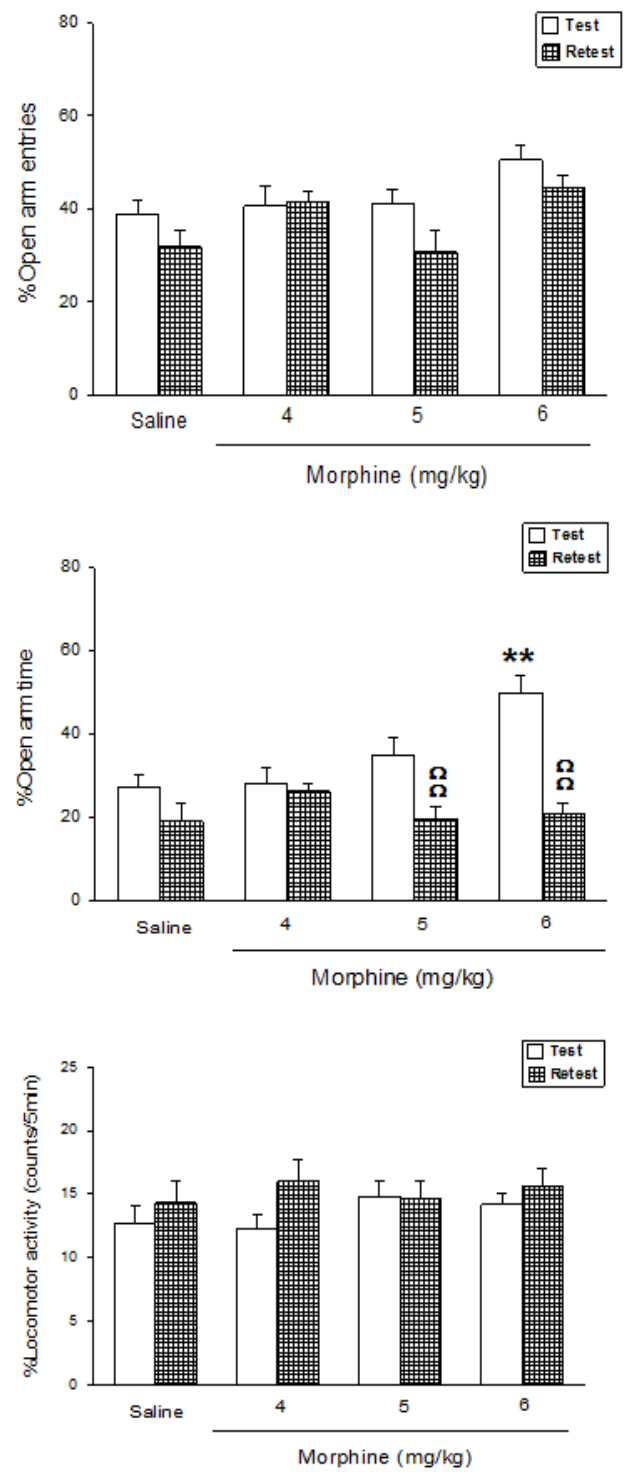

شكل 1- تأثير مورفين بر رفتارهاى شبهاضطر ابى و شكل گيرى حافظه.

Fig. 1. Effects of morphine injection on anxiety and memor.

$\left.\mathrm{F}_{\text {treatment } \times \text { session }}(3,40)\right],[(1,40)=283.291 ; p<0.001$ 3.192; p >0.05]. مى توان جنين نتيجه گرفت كه كلونيدين و مورفين، داراى اثر سينرزيستيك يا همافزا در كاهش ميزان

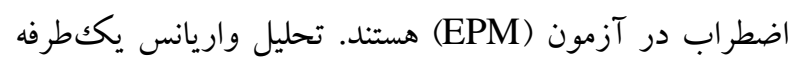
نشان داد كه ميزان فعاليت حركتى دريى تزريق كلونيدين [F (3,20)= $4.00 ; p<0.05$ ] (F $\mu \mathrm{g} / \mathrm{rat}$ ) two- تزريق كلونيدين به همراه مورفين نيز با توجه به تحليل

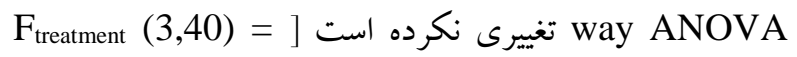
$\mathrm{F}],\left[\mathrm{F}_{\text {session }}(1,40)=3.779, p<0.05\right],[0.129, p<0.05$ . [treatment $\times$ session $(3,40)=0.098, p<0.05$
تأثير كلونيدين به تنهايع يا همراه با مورفين بر رفتارهاى شبهاضطر ابى و تشكيل حافظه

تأثير كلونيدين به تنهايى يا با مورفين بر حافظه و اضطراب در

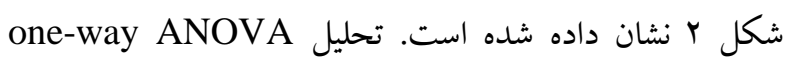

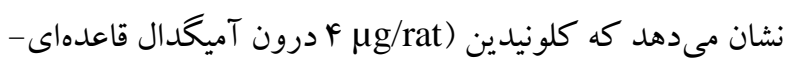

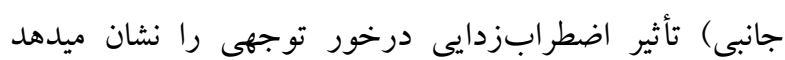

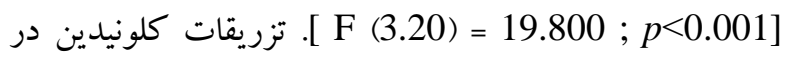
تمام دوزها به همراه مورفين تفاوت معنادارى را در مقادير

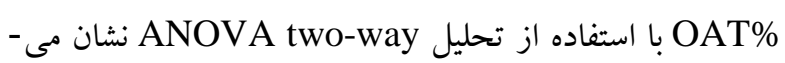
دهد 


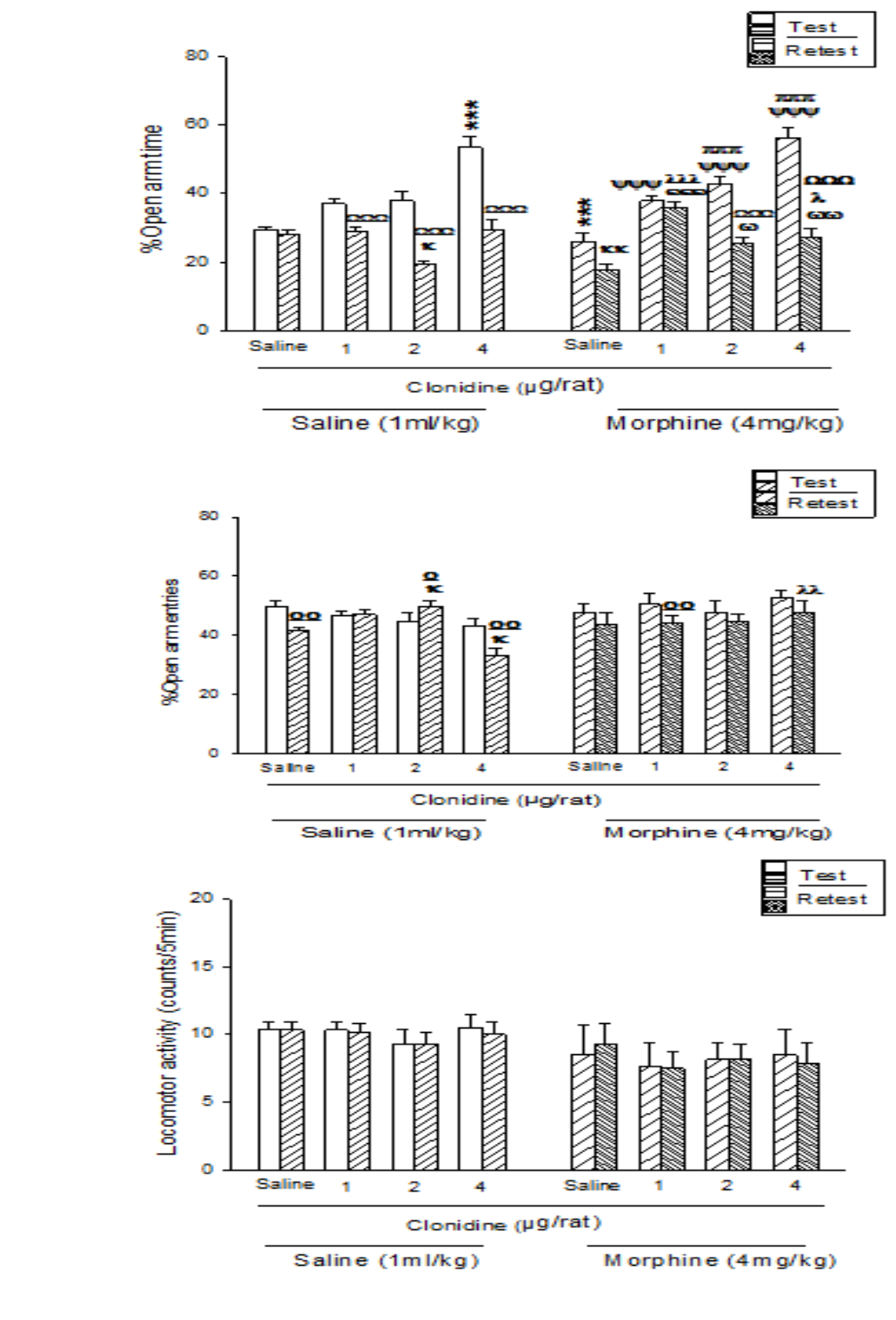

شكل r- تأثير تزريق كلونيدين درون BLA، به تنهايى يا به همراه با مورفين بر رفتارهاى شبهاضطرابى و بهخاطر آورى حافظه.

Fig. 2. Effects of clonidine injection intra-BLA, only or with morphine on anxiety and memory retrieval.

OAE\% و Oهدست آمده از آزمون روز اول OAT\% مقايسه با روز دوم (retest) حكايت دارد كه نشاندهنده وجود حافظه در روز دوم در مقايسه با روز اول است. مقادير آمارى مربوط به آزمونهاى Tepeated measures و نيز اين يافته ها را تأييد كردند. [ F $\left.F_{1 \times \text { group }}(3,20)=\right],\left[F_{\text {group }}(1,20)=20.506, p<0.001\right]$ .[37.751, $p<0.001$

تأثير تزريق يوهيمبين درون BLA، به تنهايى يا همراه با مورفين بر رفتارهاى شبهاضطر ابى و بهخاطر آورى حافظه
تحليل واريانس يككطرفه در بال اثر كلونيدين بر حافظه تفاوت معنادارى رادر مقدار [ $\mathrm{F}$ retest مذكور دريى تزريق كلونيدين و مورفين بهصورت توأمان، افزايش معنىدارى را در مقادير OAT\% براساس تحليل واريانس دوطرفه [ Ftreatment $(3,40)=14.266, p<0.001$ ) $\left.\left.\mathrm{F}_{\text {treatment } \times \text { session }}\right] \mathrm{F}_{\text {session }}(1,40)=0.010, p<0.001\right]$ (3,40) = 9.966, $p<0.001$ دادند. آزمونهاى T انجامشده نيز از تفاوت معنادارى در مقادير 
درون BLAg/rat)

كاهش يافت. [ [ [

[ [ F و فرمول ديخر به شكل
تحليل one-way ANOVA نشان مىدهد كه يوهيمبين با دوز داده و موجب افزايش ميزان اضطراب شده است (شكل r). تحليل واريانس دوطرفه نشان داد كه اثر اضطرابزداى مورفئ فران

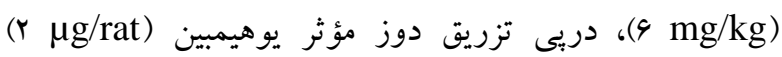
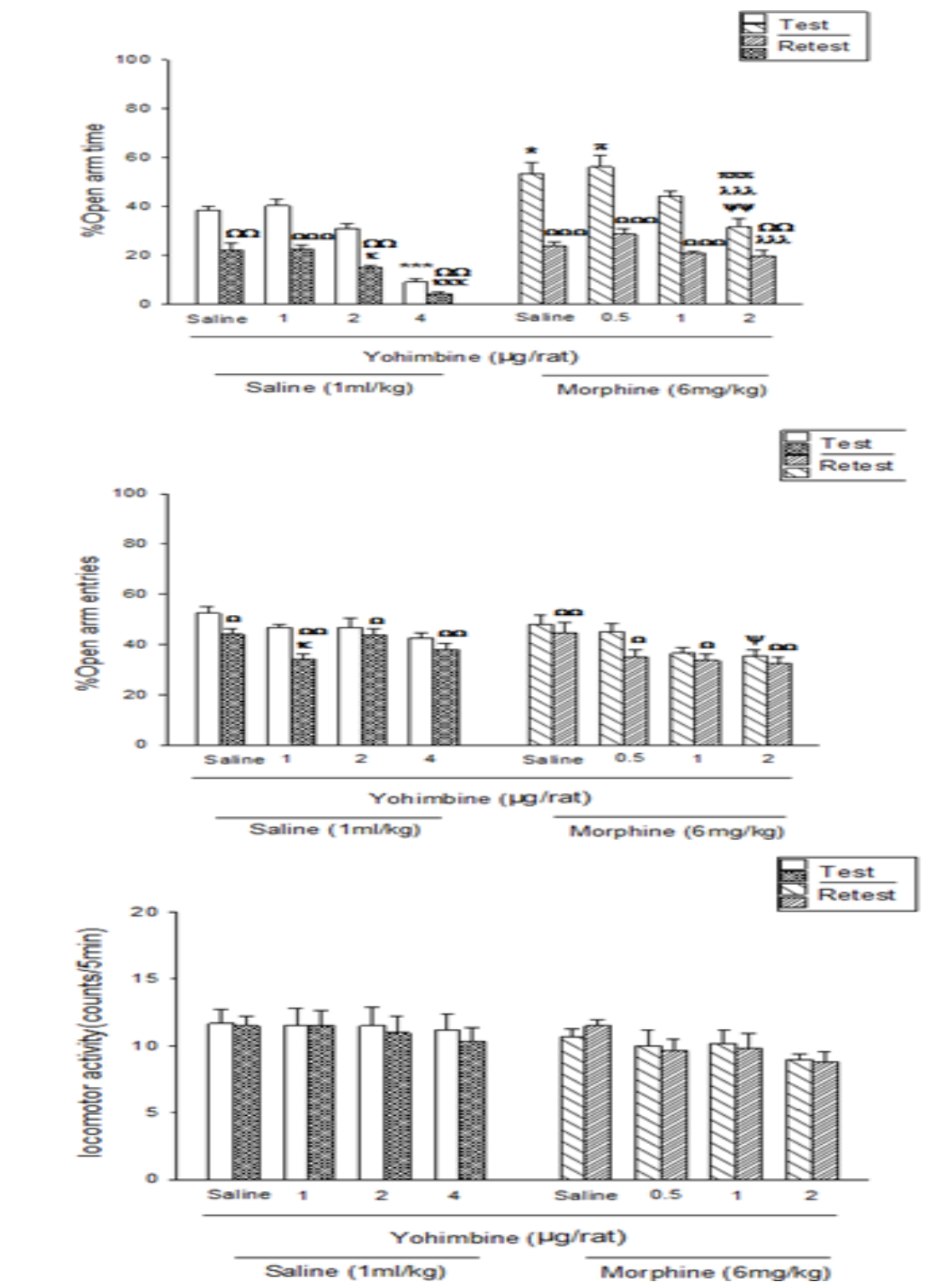

شكل r- تأثير تزريق يوهيمبين درون BLA، به تنهايى يا همراه با مورفين بر رفتارهاى شبهاضطر ابى و به خاطر آورى حافظه.

Fig. 3. Effects of yohimbin injection intra-BLA, only or with morphine on anxiety and memory retrieval.

با استفاده از تحليل واريانس دوطرفه مىتوان نتيجه گرفت كه

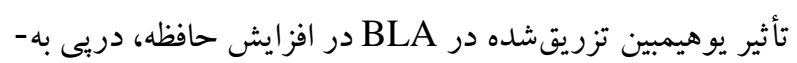

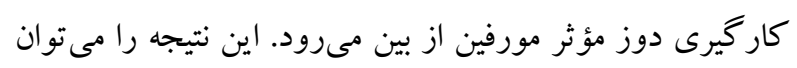

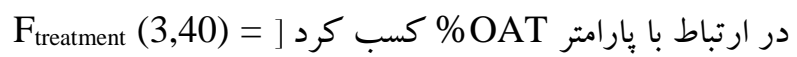
$\left[\mathrm{F}_{\text {session }}(1,40)=31.117, \quad, \quad[20.739, p<0.001\right.$ . [ [ $\mathrm{F}_{\text {treatment } \times \text { session }}(3,40)=4.992, p<0.01,[p<0.001$ مقادير آمارى مربوط به آزمون T T و آزمون
[ $\mathrm{F}_{\text {treatment }} \times$ session $(3,40)=0.798, p<0.05$ واريانس يككطرفه، نشاندهنده كاهش معنادارى در مقدار

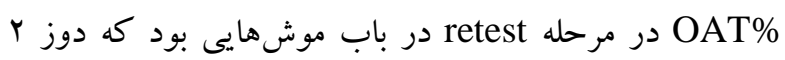

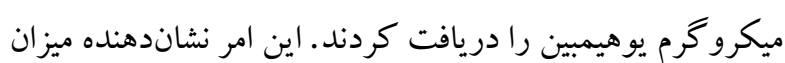
افزايش اكتساب حافظه در بي دريافت متعاقب يوهيمبين است. [ $[\mathrm{F}(3,20)=4.97 ، p<0.05]$ 
يا دوز زير آستانهاى يوهيمبين تيمار شده بودند در حضور فقدان

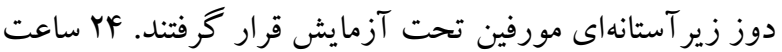

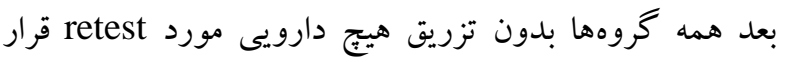

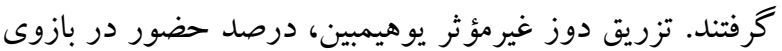
باز [F تعداد ورود به بازوى باز [ 2.230 = (4,25 كلوييدين در مرحله test را كاهش داد. اين كاهش كمتر از

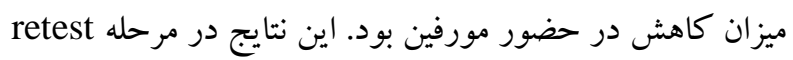
براى OAE\% و [ F ] [F (4,25)=8.501, p > 0.001] measures $\left.\left.F_{\text {group }}(1,20)=6.742, \quad\right]=291.856, p<0.001\right]$ $. p<0.01] . \quad\left[\mathrm{F}_{1 \times \text { group }}(3,20)=8.714, p<0.01\right]$

تأثير كلونيدين و يوهيمبين يا كلونيدين و يوهيمبين همراه با مورفين بر رفتارهاى شبهاضطر ابى و تشكيل حافظه شكل F، تأثير تزريق درون BLA يوهيمبين را بر رفتار جستو جو گرانه القاشده بهوسيله كلونيدين و كلونيدين به همر اه مورفين نشان مىدهد. موشها، ها دقيقه يساز تزريق سالين ( ml/rat يا كلونيدين (F
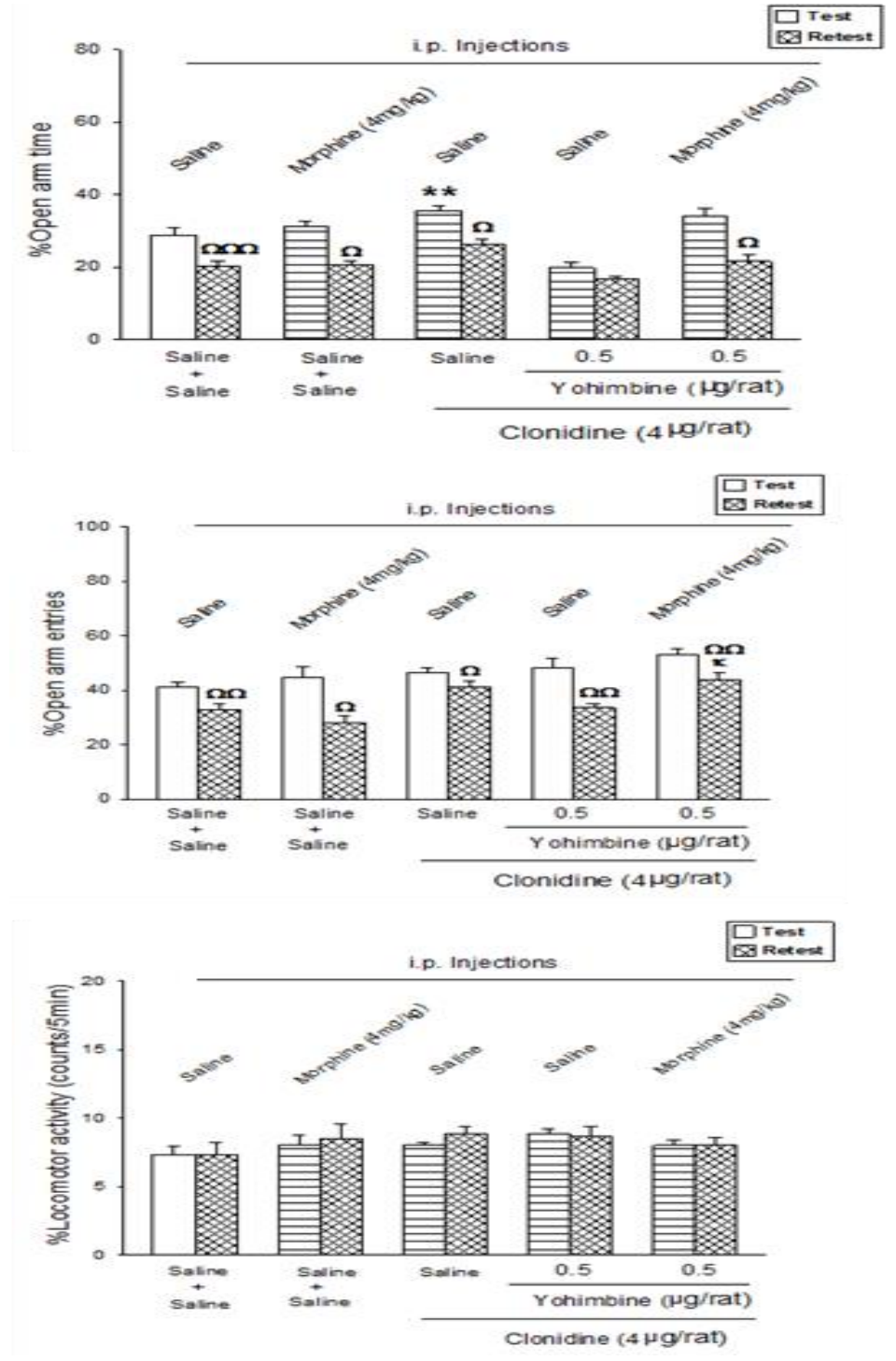

شكل F- تأثير كلونيدين و يوهيمبين يا كلونيدين و يوهيمبين همراه با مورفين بر رفتارهاى شبهاضطر ابى و تشكيل حافظه.

Fig. 4. Effects of clonidine and yohimbin or clonidine and yohimbin with morphine injections intra-BLA, on anxiety and memory retrieval. 
نتايج تحقيق حاضر نشان داد كه در تزريق درونصفاقى دوزهاى

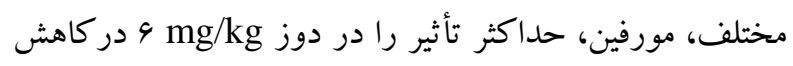

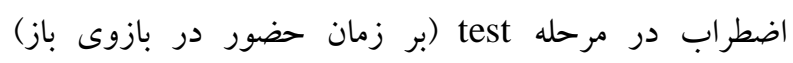

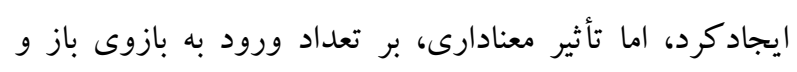

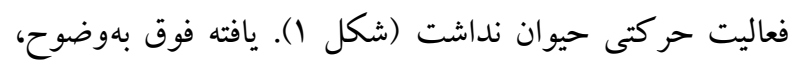

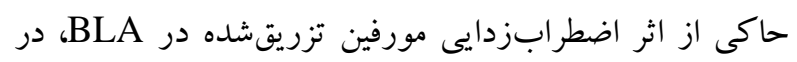

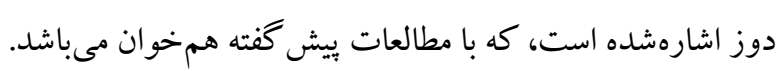
در مطالعه بيشرو، موشهايى كه دوزهاى ها و 9 ميلى گرم

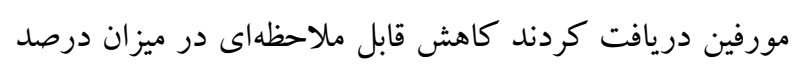

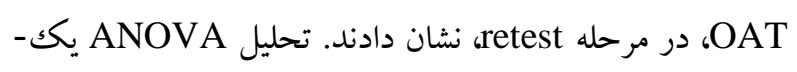

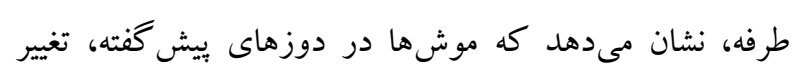

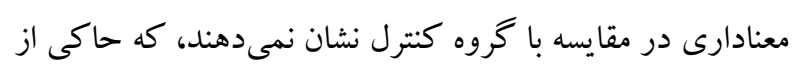
حفظ سطوح اكتساب حافظه علىرغم تغييرات اضطرابى ايجادشده است.

از سوى ديخر، آزمون T نشاندهنده ايجاد تفاوت معنادار بين

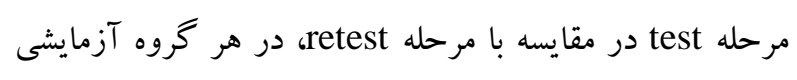
است. نتايج تحليل repeated measures، از تفاوت معنادار بين تغييرات سطوح OAT، در مراحل test، و تغييرات آن در تحريل مر احل retest، حكايت مى كنند.

درمجموع، مىتوان نتيجه گرفت كه اعمال سيستميك مورفين موجب افزايش يا كاهش معنادارى در اكتساب حافظه نشده نرفه

مطالعات متعدد بيشبالينى نشان داده است كه استرس و

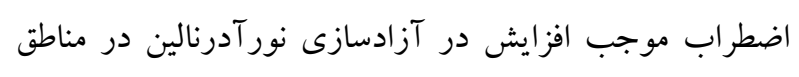

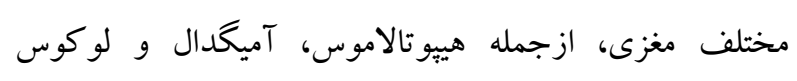

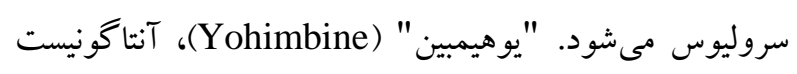

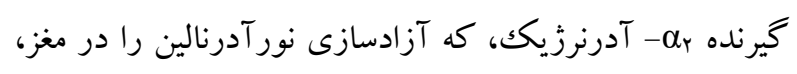

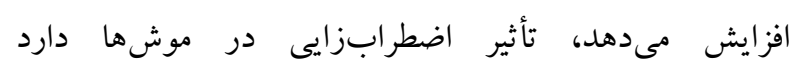
(Tanakata et al., 2000)

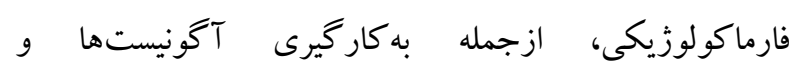
آنتاكونيستهاى مختلف گيرنده

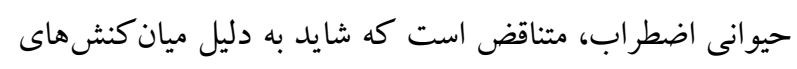

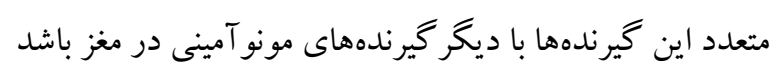

اضطراب، بِاسخ ساز كار كنندهاى است كه فرد را براى رويارويى

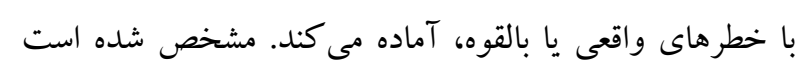

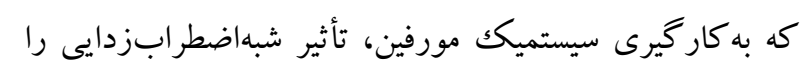
القا مى كند (Zarrindast et al., 2005). درمقابل،

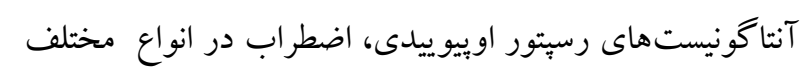

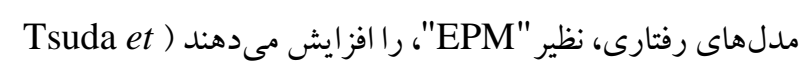

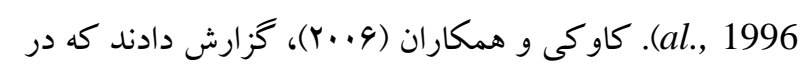

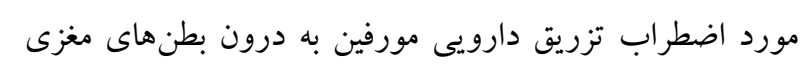

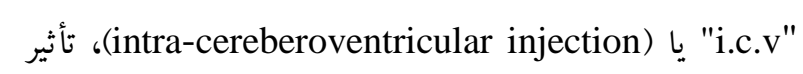
درخور توجهى دارد، كه احتمالاً ازطريق سيستم

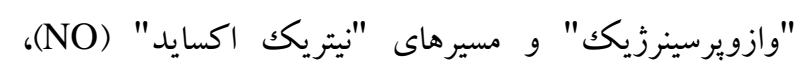

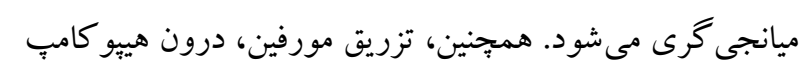

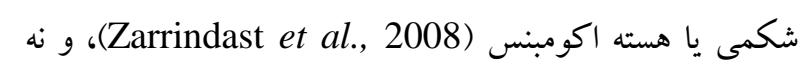

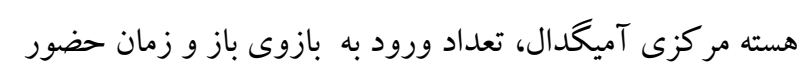

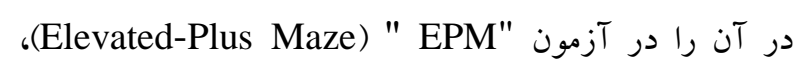
افزايش مىدهد، كه نشاندهنده اثر شبهاضطرابزدايى آن است

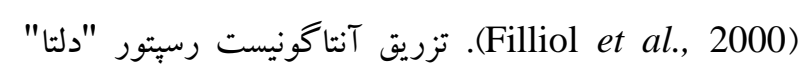

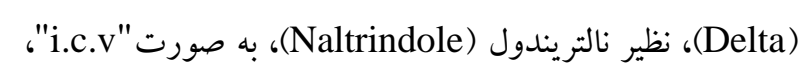

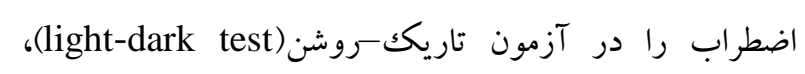

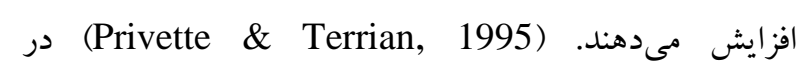

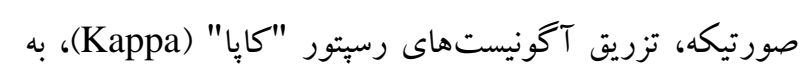
صورت سيستميك، موجب كاهش اضطراب در موشها مىشوند (Sasaki et al., 2002) آنتاكونيست رسيتورهاى ب-اوييوييدى، مثل نالوكسان، درون

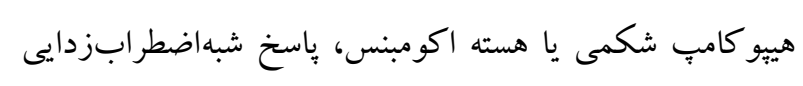

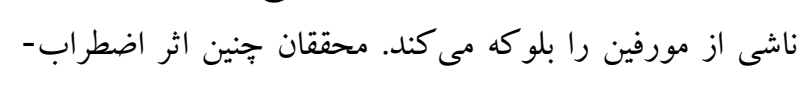

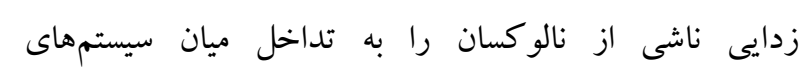

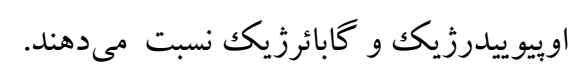

مورفين ازطريق رسبتورهاى ب- اوييوييدى، اثر اضطرابزدايى

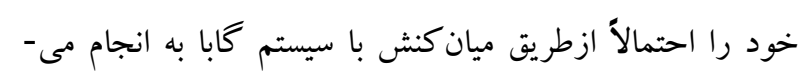

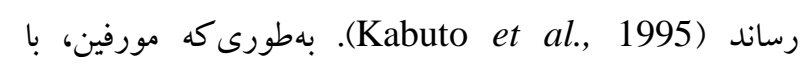

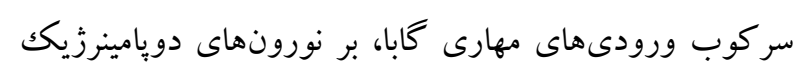

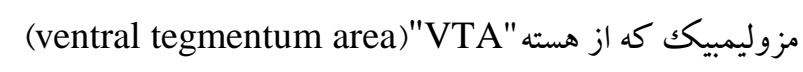

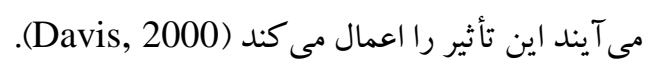


كه آميگدال اثر تسهيل كنندگى هورمونهاى استرس بر حافظه را

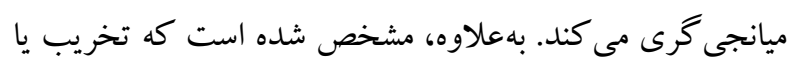

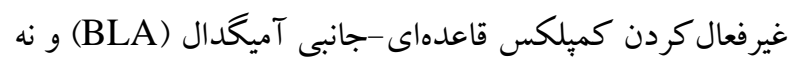

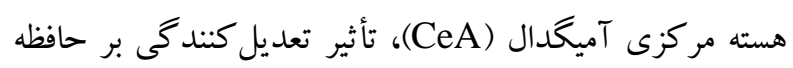

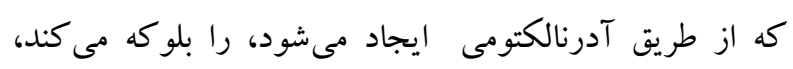
همان گونه كه دريى اعمال يا تزريق كلو كو كورتيكوييدهاى آدرني

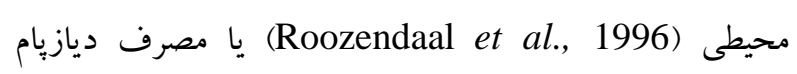
(Tomaz et al., 1992)

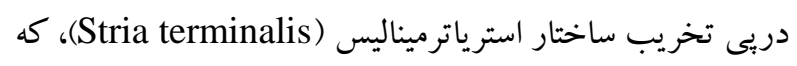
يكى از مسيرهاى اصلى خروجى آميخدال است، حاصل شده

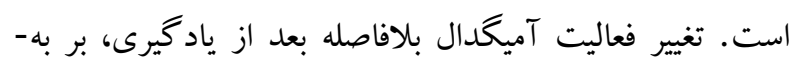

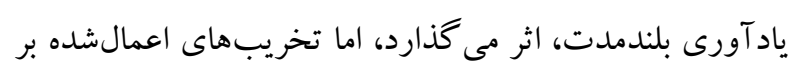
BLA هيج تأثيرى بر اين روند ندارد (Parent et al., 1995).

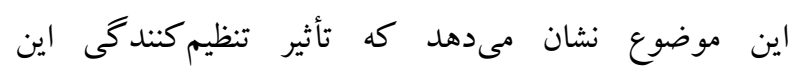
مودوليتورها، از تغيير ذخيره حافظه در آميخدال ناشى نمى شوده،

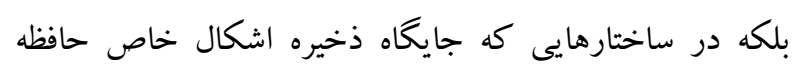
هستند صورت مى گيرد (Cahill \& McGaugh , 1999). به-

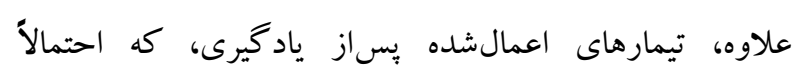

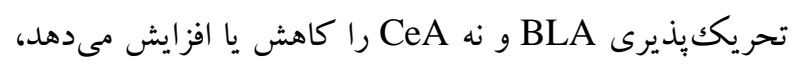
به خاطر آورى را به ترتيب كم و زياد مى كند؛ براى مثال تزريق

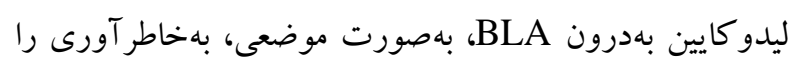

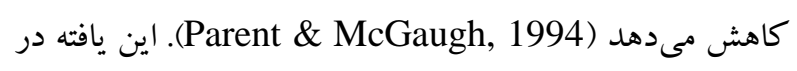
مورد تزريق آكونيستهاى GABA

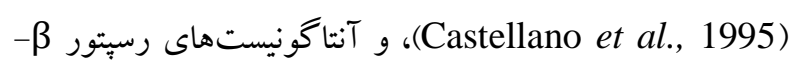
آدرنرزيك (Roozendaal et al., 1995) نيز صادق است.

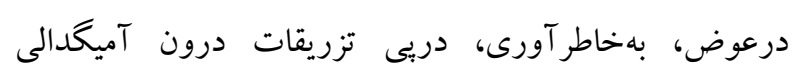

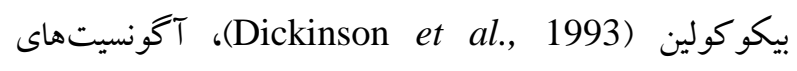

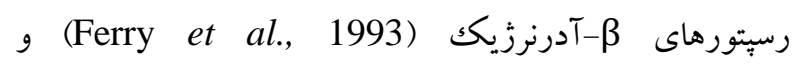
موسكارينى (Salinas et al., 1993) افزايش مى ميابد.

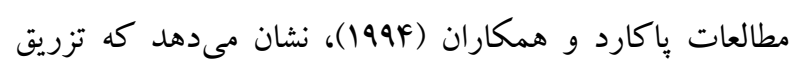

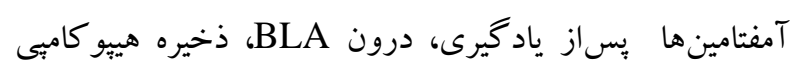

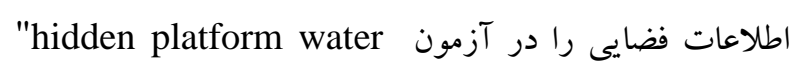

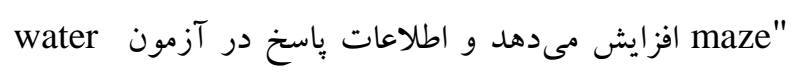

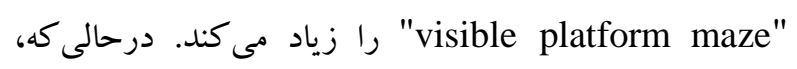
تزريق درون آميگدالى ليدوكايين، بلافاصله قبل آزمون به دراد
Schramm et al., 2001) تحريك آميخدال از هسته لو كوس سروليوس، بر نورونهاى

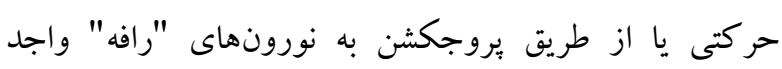

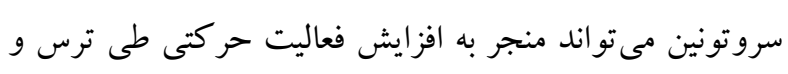

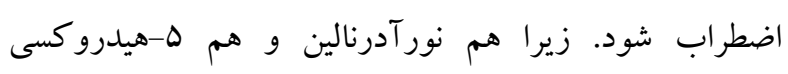

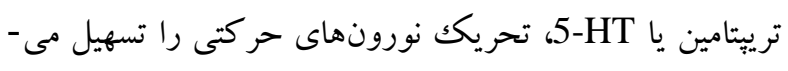

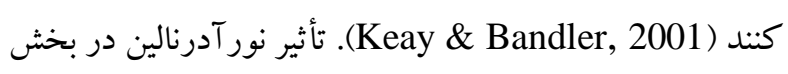

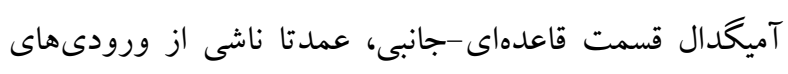

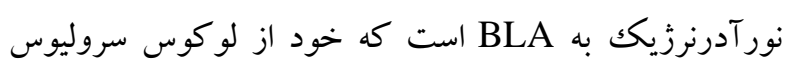
منشأ مى گيرند (Fallon et al., 1978). تأثير نور آدرنالين در آميكدال قاعدهاى-جانبى، عمـدتا ناشى از

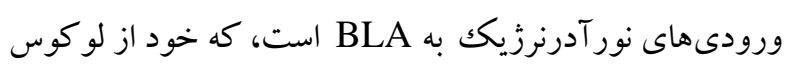
سروليوس منشأ مى گيرند (Fallon et al., 1978). شو اهد مختلف، نشان مـىدهند كـه سـرعت تخليـه نـورونهـاى

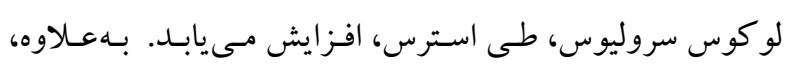

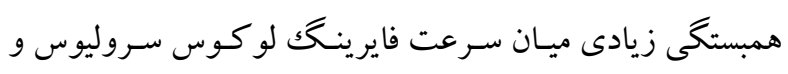

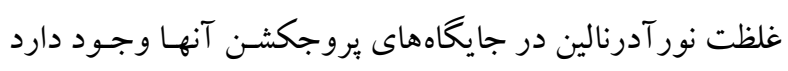

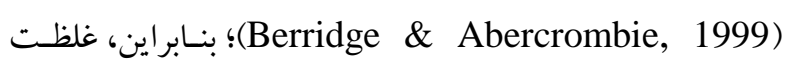
افزايش يافته نور آدرنالين دريى استرس در آميكدال مشاهده شده

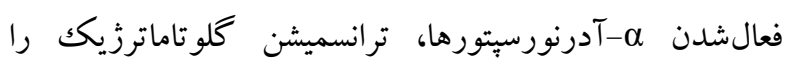
كاهش مىدهد (Ferry et al., 1997). مطالعات نشان داده است كه زير نوع م- - آدرنورسيتور، بهصورت بس سينايسى قرار

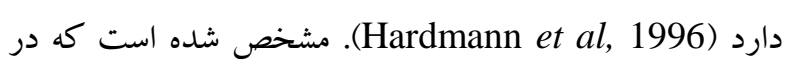

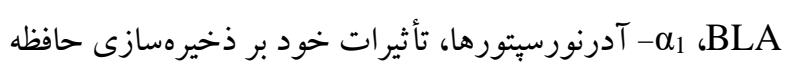

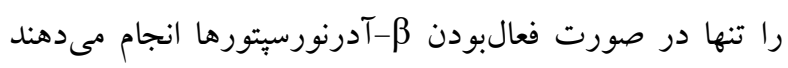
(Starke, 2001)

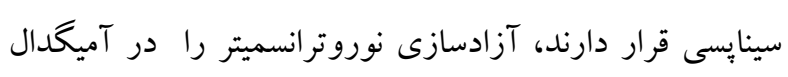
مهار مى كنند (Ferry, 1997). مطالعات اخير كه براساس تحريك الكتريكى ساختارهاى مغزى جداشده، انجام گرفته است، حاكى از نقش آميكدال در تعديل تثبيت حافظه است (Gold \& McGaugh, 1975). مطالعاتى كه براساس تخريب يا ايجاد ضايعه انجام شده است نشان مىدهد 
سوى ديخر، تحليل واريانس دوطرفه نيز تفاوتهاى معنادارى در

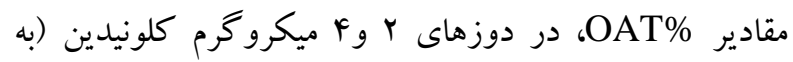

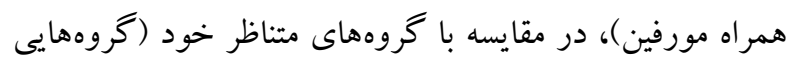

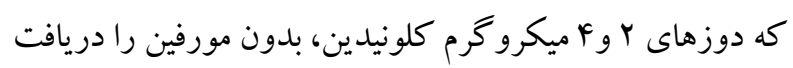

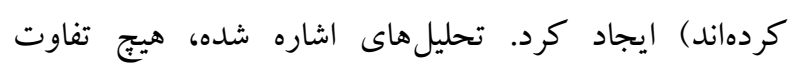
معنادارى را در مقادير OAE\% نشان نداد (شكل rاد ب). مى توان

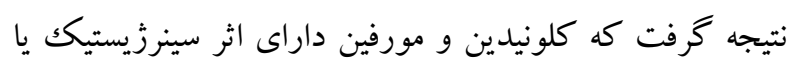

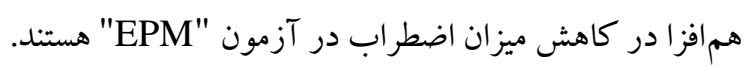
در باب اثر داروهاى فوق بر حافظه، تحليل واريانس يككطرفه

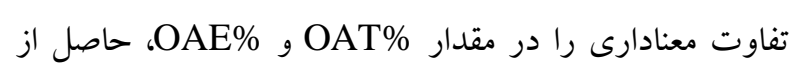
تزريق دوزهاى مختلف كلونيدين، در مرحله retest، در مقايسه

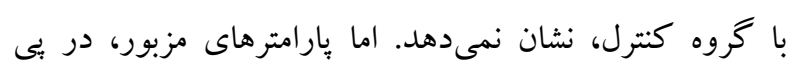
تزريق كلونيدين به همراه مورفين افزايش معنادارى در مقايسه با بارديا

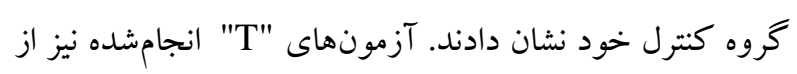

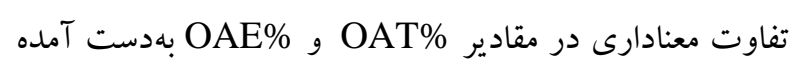

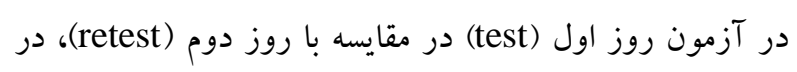
آزمايش هاى اخير حكايت مى كند، كه نشاندهنده وجود حون حافظه در روز دوم در مقايسه با روز اول است.

درمجموع، مىتوان نتيجه گرفت كه تزريق كلونيدين درون

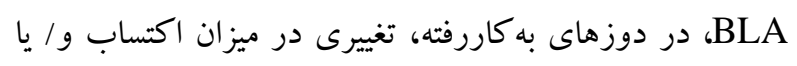

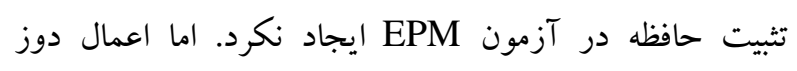

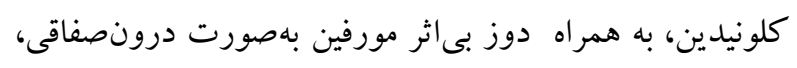

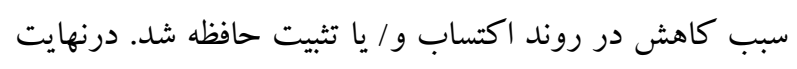

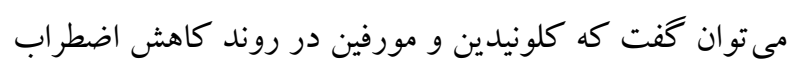

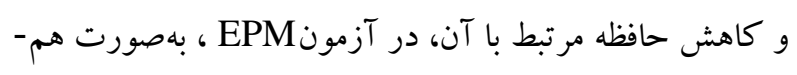
افزا عمل مى كنند. كفتنى است كه در كليه آزمايشهاى هائ فوق،

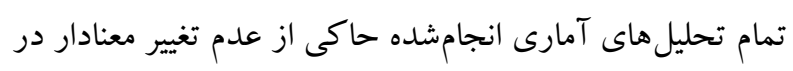

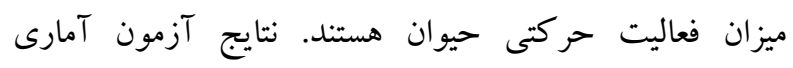
repeated measures تغييرات در اضطر اب و حافظه است.

در مجموعه آزمايشهاى بعدى، تزريق يوهيمبين بهدرون BLA،

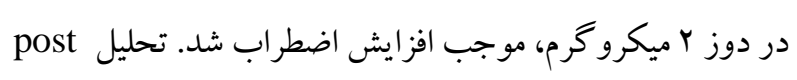

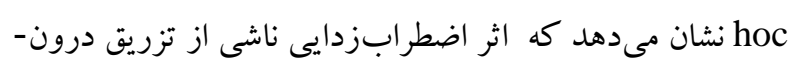

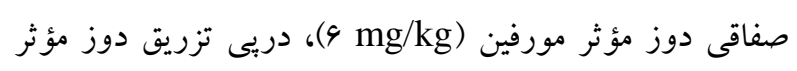

يادآورى، تأثيرى بر دو نوع آزمون ذكرشده نخواهد كذاشت Packard et al., 1994)

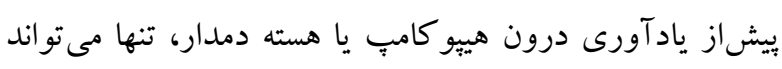
تأثير ظرفيت يابى حافظه ناشى از تزريق درون آميكدالى آمفتامين

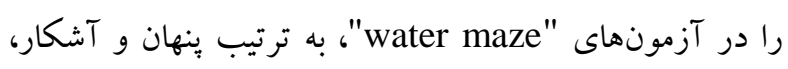
بلو كه كند (Packard \& Teather, 1998). درمجموع، اين

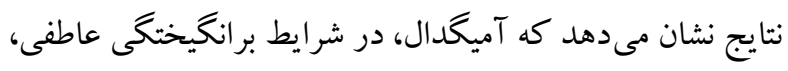

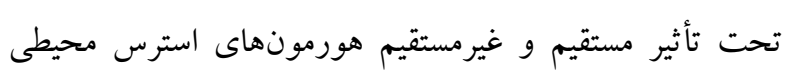

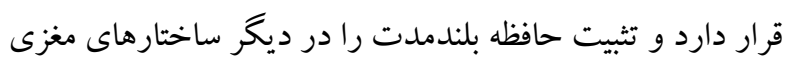

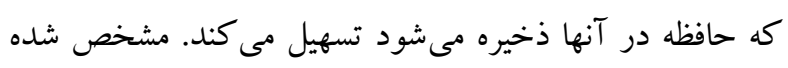

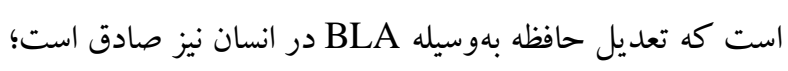

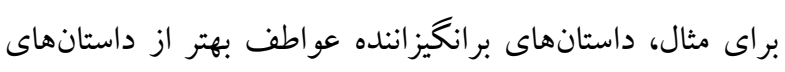

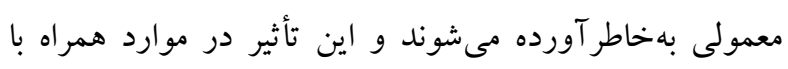
تخريب آميكدال غايب است (Adolphs et al.,1997). تأثير نور آدرنالين، كه عمدةًاً ناشى از مهار بيشسينإِى است،

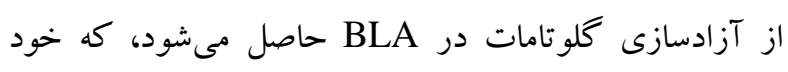

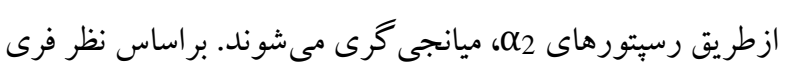

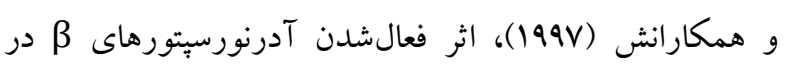
BLA به مراتب از اهميت كمترى برخوردار است. نشان داده

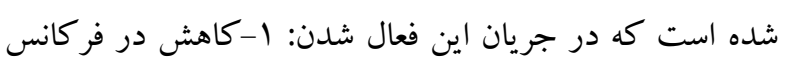

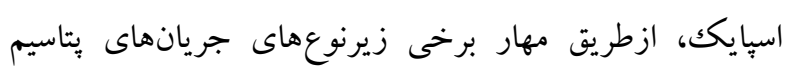

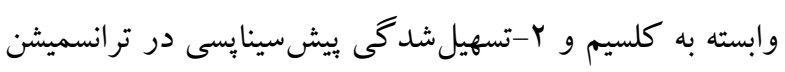

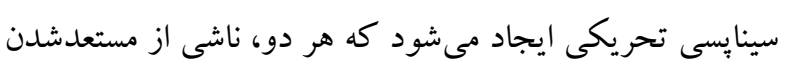

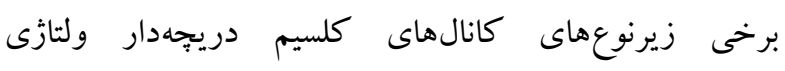
است (Huang et al., 1996; Ferry et al., 1997). در مطالعه حاضر، تزريق دوز

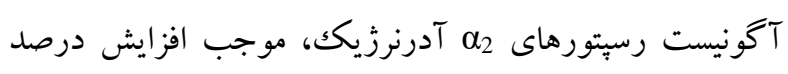

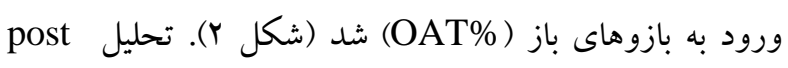
نشان مىدهد كه كلونيدين در دوز اشارهشده سبب بروز

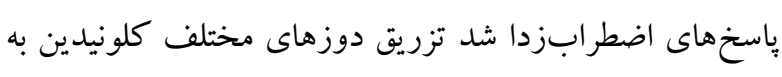

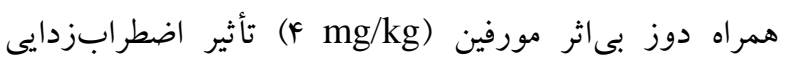
درخورتوجهى را نشان مىدهد. تحليل واريانس يككطرفه، نشان مىدهد كه تزريقات فوق در تمام دوزهاى كلونيدين به همراه

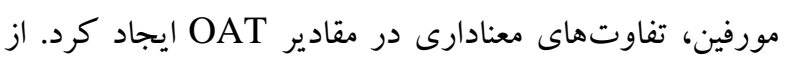


اعمال درونصفاقى مورفين به همراه داروهاى فوق نيز تا حدودى اثر اضطرابزدايى ايجاد كرد، اما نتوانست آن را به سطح اوليه بركرداند. در مورد حافظه نيز مشخص شد كه تمام كروههاى آزمايشى حافظه داشتند، اما تغيير معنادارى دريى

$$
\text { آزمايش ها، ديده نشد (شكل \&). }
$$

با توجه به آزمايشهاى انجام شده مىتوان نتيجه كرفت كه فعالشدن سيستم نور آدرنرزيكك آلفا و بتا، جنان كه در بخش نتايج ديده مىشود، موجب كاهش اضطراب شده و بلو كهشدن رسبتورهاى آن توسط آنتاكونيستهاى نور آدرنرزيك،، موجب معكوس شدن اثر اضطرابزدايى اشارهشده مىشود.

در آزمايشهاى مربوط به ثبت حافظه، با توجه به نتايج تحليل هاى مختلف آمارى، دست كم در دوزهايى كه در اين آزمايش به كار رفته است، آكونيستهاى نور آدرنرزيك،، تأثير درخور توجهى بر تثبيت حافظه ندارند. اما اعمال آنتاگونيستهاى نور آدرنرزيكك در هسته BLA سبب افزايش تثبيت حافظه شدند. به كار گيرى مورفين، تأثيرى بر تثبيت حافظه نداشت.

به نظر مىرسد سيستمهاى إيوييدرزيكك و نور آدرنرزيكك، هردو سبب بروز تأثير مشابه بر اضطراب و تثبيت حافظه شدند، اما با توجه به يافته ها، اين دو سيستم بهصورت موازى عمل مى كند و

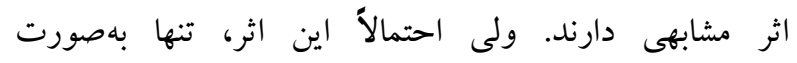

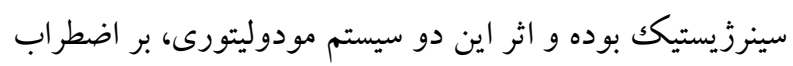
و تثيت حافظه ناشى از آن در هسته BLA مستقل از هم است. از سوى ديخر، تحليلهاى آمارى، نشان از ارتباط مستقيم بين دو رفتار مذكور دارند كه خود تأييدى بر ارزش سازشى اضطراب در مواجهه بعدى با يكك عامل اضطر ابزا است.

\section{References}

Aggleton, J.P. 2000. The amygdala: a functional analysis. University Press. Oxford.

Adolphs, R., Cahill, L., Schul, R. and Babinsky, R. 1997. Impaired declarative memory for emotional stimuli following bilateral amygdale damage in human. - Learn. Mem. 4: 291-300.

Berridge, C.W. and Abercrombie, E.D. 1999. Relationship between locus coeruleus discharge rates and rates of norepinephrine release within
يوهيمبين (r Mg/rat)، كاهش يافت (شكل r). در باب اثر داروهاى مزبور بر حافظه، آزمونهاى T انجامشده نشان مىدهند كه تمامى گروههاى آزمايشى در روز دوم (مرحله retest)، نسبت به روز اول حافظه داشتند. تحليل واريانس يككطرفه، نشاندهنده يكك كاهش معنادار در مقدار OAT\%، در مرحله retest دريافت كردند، در مقايسه با گروه كنترل است. اين امر نشاندهنده افزايش در ميزان اكتساب حافظه، دريى دريافت اين دوز از يوهيمبين در اين موشهاست. ازسوى ديخر، براساس نتايج تحليل واريانس يككطرفه، تزريق دوز مؤثر مورفين (9 mg/kg)، دريى تزريق دوز مؤثر يوهيمبين (Y Mg/rat)، تفاوت معنادارى را در مقايسه با گروه كنترل خود نشان نمى دهد. علاوهبراين، تحليل واريانس دوطرفه نيز، نشاندهنده يكك افزايش بارز در ميزان OAT\% كروهى است كه دوز مؤثر يوهيمبين را دريافت كرده بودند. بنابراين، مىتوان نتيجه گرفت كه تأثيرات يوهيمبين تزريقشده در BLA در افزايش حافظه، دريى به كارگيرى دوز مؤثر مورفين از بين مىرود. گفتنى است كه آزمونهاى آمارى repeated measures روند تغييرات در ميزان اضطراب و حافظه هستند. اين امر نشان مىدهد كه تغيير در ميزان اضطراب دريى اعمال داروهاى اشارهشده، بر روند تغييرات مربوط به اكتساب حافظه تأثير مى خذارد و دو رفتار مذكور با يكديخر همبستكى دارند.

در آزمايش هاى مربوط به ميان كنش كلونيدين و يوهيمبين همراه با مورفين تحليل واريانس يككطرفه، نشان مىدهد كه دوز بى اثر يوهيمبين توانست تأثير اضطرابزدايى كلونيدين را بركرداند.

neocortex as assessed by in vivo microdialysis. Neurosci. 93: 1263-1270.

Cahill, L., Haier, R., Fallon, J., Alkire, M., Tang, C., Keator, D., Wu, J. and McGaugh,

J.L. 1996. Amygdala activity at encoding correlated with long-term, free recall of emotional information. - Proc. Nat. Acad. Sci. 93: 8016-8021.

Cahill, L. 2000. Modulation of long-term memory storage in humansby emotional arousal: adrenergic 
activation and the amygdala. In: Aggleton, J.P. (Ed.), the Amygdala: A Functional Analysis. Oxford University Press, Oxford. pp. 425-445.

Castellano, C., Brioni, J.D., Nagahara, A.H. and McGaugh, J.L. 1989. Post-training systemic and intraamygdala administration of the GABA-B agonist baclofen impairs retention. - Behav. Neural. Biol. 52: 170-179.

Davis, M. and Shic, J. 2000. The amygdale. - Curr. Biol. 10: 131-135.

Davis, M. 2000. The role of the amygdala in conditioned and unconditioned fear and anxiety. In The Amygdala, J.P. Aggleton, ed. - Oxford University Press. UK. pp. 213-288.

Davis, M. and Whalen, P.J. 2001. The amygdala: vigilance and emotion. - Mol. Psychiatr. 6:13-34.

Dickinson, A.H., Mesches, M.H., Coleman, K. and McGaugh, J.L. 1993. Bicuculline administered into the amygdala blocks benzodiazepine-induced amnesia. - Behav. Neural. Biol. 60: 1-4

Duque, A., Balatoni, B., Detari, L. and Zaborszky, L. 2000. EEG correlation of the discharge properties of identified neurons in the basal forebrain. - J. Neurophysiol. 84: 1627-1635.

Fallon, J.H., Koziell, D.A. and Moore, R.Y. 1978. Catecholamine innervations of the basal forebrain. II. Amygdala, suprarhinal cortex and entorhinal cortex. - J. Comp. Neurol. 180: 509-531.

Fanselow, M.S. and Poulos, A.M. 2005. The neuroscience of mammalian associative learning. Annu. Rev. Psychol. 56: 207-234.

Ferry, B., Magistretti, P.J. and Pralong, E. 1997. Noradrenaline modulates glutamate-mediated neurotransmission in the rat basolateral amygdala in vitro. - Eur. J. Neurosci. 9: 1356-1364.

Filliol, D., Ghozland, S., Chluba, J., Martin, M., Matthes, H.W., Simonin, F., Befort, K., Gaveriaux-Ruff, C., LeMeur. M., Valverde, O., Maldonado, R. and Kieffer, B.L. 2000. Mice deficient for delta- and mu-opioid receptors exhibit opposing alterations of emotional responses. - Nat. Genetics 25: 195-200.

Gold, P.E. and McGaugh, J.L. 1975. A singletrace, two process view of memory storage processes. In: Deutsch, D., Deutsch, J.A. (Eds.), Short-Term Memory. - Academic Press. New York. pp. 355-378.

Hardmann, J.G., Limbird, L.R., Molinoff, P.B., Ruddon, R.W. and Gilman, A.G. 1996. Catechol amines and sympathomimetic drugs: endogenous catechol amines. Pharmacological Basis of Therapeutics. (9th edn). - McGraw-Hill. New York. pp. 204-248.
Introini-Collison, I.B., Ford, L. and McGaugh, J.L. 1995. Memory impairment induced by intra amygdala b-endorphin is mediated by noradrenergic. - Influences Neurobiol. Learn. Mem. 63: 200-205.

Johnson, S.W. and North, R.A. 1992. Opioids excite dopamine neurons by hyperpolarization of local interneurons. - J. Neurosc. 12: 483-488.

Kabuto, H., Yokoi, I., Iwaya, K. and Mori, A. 1995. Monoamine release in the rat striatum is induced by delta-guanidinovaleric acid and inhibited by GABA agonists. - Life. Sci. 56: 1741-1748.

Keay, K.A. and Bandler, R. 2001. Parallel circuits mediating distinct emotional coping reactions to different types of stress. - Neurosci. Biohav. Rev. 25: 669- 678

Le Doux, J.E. 2000. Emotion circuits in the brain. Annu. Rev. Neurosci. 23:155-184.

Liang, K.C., McGaugh, J.L., Martinez, jUJ.L. Jensen, R.A., Vasquez, B.J. and Messing, R.B. 1982. Post training amygdala lesions impair retention of an inhibitory avoidance response. Behave. Brain. Res. 4: 237-249.

Maren, S. and Quirk, G.J. 2004. Neuronal signaling of fear memory. - Nature Rev. Neurosci. 5: 844-852.

McGaugh, J.L. 2004. The amygdala modulates the consolidation of memories of emotionally arousing experiences. - Annu. Rev. Neurosci. 27: 1-28.

McGaugh, J.L. and Gold, P.E. 1976. Modulation of memory by electrical stimulation of the brain. In: Rosenzweig, M.R., Bennett, E.L. (Eds.), Neural Mechanisms of Learning and Memory. - MIT Press. Cambridge. pp. 549-560.

McGaugh, J.L., Cahill, L. and Roozendaal, B. 1996. Involvement of the amygdala in memory storage: interaction with other brain systems. Proc. Natl. Acad. Sci. 93: 13508-13514.

Millan, M.J. 2003. The neurobiology and control of anxious states. - Prog. Neurobiol. 70: 83244-83251.

Koks, S., Soosaar, A., Voikar, V., Bourin, M. and Vasar, E. 1999. BOC-CCK-4, CCK (B) receptor agonist, antagonizes anxiolytic-like action of morphine in elevated plus-maze. - Neuropeptides. 33: $63-69$

Packard, M.G. and Teather, L.A. 1998. Amygdala modulation of multiple sensory systems: hippocampus and caudate putamen. - Neurobiol. Learn. Mem. 69: 163-203.

Parent, M.B., Quirarte, G.L., Cahill, L. and McGaugh, J.L. 1995. Spared retention of inhibitory avoidance learning after post-training amygdale lesions. - Behav. Neurosci. 109: 803-807. 
Privette T.H and Terrian D.M. 1995. Kappa opioid agonists produce anxiolytic-like behavior on the elevated plus-maze. - Psychopharmacology 118: 444-450.

Quirarte, G. L., Roozendaal, B. and McGaugh, J.L. 1997. Glucocorticoid enhancement of memory storage involves noradrenergic activation in the basolateral amygdala. - Proc. Natl. Acad. Sci. 94: 14048-14053.

Roozendaal, B., Sapolsky, R.M. and McGaugh, J.L. 1998. Basolateral amygdala lesions block the disruptive effects of long-term adrenalectomy on spatial memory. - Neurosci. 84: 453-465.

Sasaki, K., Fan, L.W., Tien, L.T., Ma, T., Loh, H.H. and Ho, I.K. 2002. The interaction of morphine and gamma-aminobutyric acid (GABA) ergic systems in anxiolytic behavior: using muopioid receptor knockout mice. - Brain. Res. Bull. 57: 689-694.

Salinas, J.A., Introini-Collison, I.B., Dalmaz, C. and McGaugh, J.L. 1997. Posttraining intraamygdala infusions of oxotremorine and propranolol modulate storage of memory for reductions in reward magnitude. - Neurobiol. Learn. Mem. 68: 51-59.

Schramm, N.L., McDonald, M.P. and Limbird, L.E. 2001. The 2A- adrenergic receptor plays aprotective role in mouse behavioral models of depression and anxiety. - J. Neurosci. 21: 48754882 .

Shin, I.C., Kim, H.C., Swanson, J., Hong, J.T. and Oh, K.W. 2003. Anxiolytic effects of acutemorphine can be modulated by nitric oxide systems. - Pharmacol. 68: 183-189.
Starke, K. 2001. Presynaptic autoreceptors in the third decade: focus on $\alpha 2$-adrenoceptors. - J. Neurochem. 78: 685-693.

Tanakata, M., Yoshida, M., Emoto, H. and Ishii, H. 2000. Noradrenaline systems inthe hypothalamus, amygdale and locus coeruleus are involved in the provocation of anxiety basic studies. - Eur. J. Pharmacol. 405: 397-406.

Tomaz, C., Dickinson-Anson, H. and McGaugh, J.L. 1992. Basolateral amygdala lesions block diazepam-induced anterograde amnesia in an inhibitory avoidance task. - Proc. Natl. Acad. Sci. 89: 3615-3619.

Tsuda, M, Suzuki, T, Misawa, $M$. and Nagase, $H$. 1996. Involvement of the opioid system in the anxiolytic effect of diazepam in mice. - Eur. J. Pharmacol. 307: 7-14.

Zarrindast, M.R., Rostami, P., Zarei, M. and Roohbakhsh, A. 2005. Intra cerebra ventricular effects of histaminergic agents' onmorphine-induced anxiolysis in the elevated plus-maze in rats. - Basic Clin. Pharmacol. Toxicol. 97: 276-81.

Zhang, H.T., Xu, Z.M., Luo, Z.P. and Qin, B.Y. 1996. Anxiogenic effect of naltrexone in socialinteraction test in rats. - Zhongguo Yao Li Xue Bao 17: 314-317.

Zarrindast, M.R., Babapoor-Farrokhran, S., Babapoor-Farrokhran, S. and Rezayof, A. 2008. Involvement of opioidergic system of the ventral hippocampus, the nucleusaccumbens or the central amygdala in anxiety-related behavior. - Life. Sci. 82: 1175-1181.

Valizadegan, F., Oryan, S. and Zarrindast M.R. 2016. Impact of the interaction between morphine and $\alpha$ noradrenergic system of basolateral Amygdala on anxiety-related behavior and memory. - Nova Biol. Rep. 3(1): 69-79.

$$
\text { ولىزاد كان، ف.، عريان، ش. و زريندست، م.ر. هوسا. بررسى ميان كنش بين مورفين و سيستم آلفا-نور آدرنرزيك در هسته قاعدهاى-جانبى آميكدال }
$$

